\title{
Introduction Contested Cultural Identities in Public Discourse
}

Ljiljana Šarić, Stefan Manz, Andreas Musolff and ingrid Hudabiunigg

Europe's eastern rim has been in constant flux ever since the watershed year of 1989. Autocratic regimes have been replaced with stable democracies, and planned economies have given way to a free-market system comprising most of the former communist countries of Central and Eastern Europe. Whereas most of these nations swiftly embarked on a course toward EU accession, the countries of the former Yugoslavia plunged into ethnic and religious infighting that left the region paralyzed for years and has left a problematic legacy until today. Further east, Turkey's longheld ambitions to join the EU received yet another setback when it was sidelined during the 2004/2007 round of enlargement. These political and economic transformations have triggered fundamental redefinitions of cultural identity. Nations and social groups have had to reposition themselves and their relationship to others within newly emerging political landscapes. Although the enlarged EU has created a new closeness between neighbors that were formerly separated by impenetrable physical and ideological barriers, at the same time it has excluded others that feel like outsiders being left behind. The break-up of the former Yugoslavia has necessitated reformulations of statehood and international relations in the Balkans.

We chose to call the área for this endeavor 'Europe's eastern rim'. With this metaphorical expression, we tried to avoid the widely used terms Mitteleuropa, Central Europe and Eastern Europe because each of these seems to imply different political and ideological conceptions for the countries from the Baltic Sea to the Mediterranean.

Mitteleuropa is a historically loaded term that focuses on the eastern part of Europe from an Austrian and German perspective, with explicit or implicit hegemonic intentions. The term Central Europe, invented in the revolutions of 1848, designates a Central European federation without Prussian or Russian domination. It reemerged in the 1980s as a kind of spiritual home for many intellectuals. However, as Maria Todorova and other Balkan experts have shown, this term is also divisive. It does not include the regions of the Balkans, but pushes them further east toward present-day Russia. Eastern Europe, in turn, clearly suggests Russian and Soviet hegemony. Furthermore, in a purely geographical sense, Eastern 
Europe extends to the Ural Mountains and includes countries outside our scope.

We, on the other hand, explicitly wanted to include the area of the former Yugoslavia, most of which, as of 2009, does not have European Union membership. In this macro-region with its overwhelming diversity of ethnic, linguistic and religious groups, one can study, as though under a magnifying glass, how the still virulent backward movement of ethnocentric xenophobia has led to internecine conflicts and ethnic cleansing. Nonetheless, in each of these newly established countries, one can also observe that media and literature are making key contributions in the interchange of ideas toward a modern and tolerant form of civil society.

Public discourse has been the main platform for negotiating transformations of cultural identity, both self-referentially and in relation to others. The aim of this book is to analyze some central themes of cultural identity construction and its transformation in public discourse. It develops the ideas of an international group of researchers on discourse analysis, initially discussed at various symposia and research projects organized by the editors (Manz et al., 2004). Our main concern in this book is discursive modes of identity construction (deconstruction, reconstruction, reformulation and invention) in the light of recent political changes in Europe, European Union enlargement and EU policy regarding southeast Europe. We focus on national and cross-national rhetorical strategies related to issues of transition within Europe.

Our book examines issues surrounding the discursive creation of cultural identity and combines theory-oriented and empirical approaches. The analyses of specific national discourses also address general methodological questions concerning rhetorical strategies and national and crossnational characteristics that play a role in the discursive presentation of identity construction. The contributions to this volume provide a multinational and multilingual perspective on discourse analysis and discursive identity formation, focusing on how issues of identity formation arise in several European languages, particularly among less-studied languages such as Slovenian, Lithuanian, Polish and Bosnian/Croatian/Serbian.

Three closely connected issues surrounding the linguistic means of identity construction and reconstruction constitute the chief topics of this volume: (1) the relationships between 'insiders' and 'outsiders' in the ongoing process of EU enlargement, (2) the perception of southeast Europe and its various nationalities as 'good guys' and 'bad guys' and (3) European insiderness and outsiderness in literary representations. These topics naturally arise from the larger historical and political framework. Since the early 1990s, actual and potential enlargement has been a key issue in debates surrounding the EU. The former East Germany made an entry through the 'back door' during the German unification process in 1990. Five years later, Austria, Sweden and Finland followed. Except 
for the negative Swedish referendum on the introduction of the euro, these accessions have been integrated relatively smoothly and hardly triggered any of the contested discourse surrounding the most recent round of eastern and Mediterranean enlargement. Considering the different nature and, not least of all, the sheer size of this last enlargement, this hardly came as a surprise. In 2004, Estonia, Lithuania, Latvia, Poland, the Czech Republic, Slovakia, Slovenia, Hungary, Cyprus and Malta joined the EU. After Romania's and Bulgaria's subsequent accession in 2007, the EU now consists of 27 member states. The enlargement process inevitably led to the exclusion of other countries. A number of candidates, including most of the Yugoslav successor states and Turkey, have been put on a waiting list.

The first part of this volume examines the discursive means by which the opposition between old and new outsiders and insiders has been created in the EU: rhetorical figures, metaphors, metonymies, symbols and conceptual blending. These semantic features are not accidental to the discourses about identity; rather, they provide the conceptual and linguistic tools for the construction, reconstruction or (re-)invention of national and cultural identities. The theoretical structure for such an approach is provided by cognitive semantics - that is, a theoretical framework comprising Conceptual Metaphor Theory (Kövecses, 2005; Lakoff \& Johnson, 1980), Conceptual Blending Theory (Fauconnier \& Turner, 2003) and Discourse Metaphor Analysis (Charteris-Black, 2004; Semino, 2008; Zinken, 2007). These approaches have been discussed variously as complementary and competing (Grady et al, 1999; Zinken \& Musolff, 2009); here, we assume their overall compatibility due to a set of shared assumptions. These include (a) an acknowledgement of the fundamental importance of metaphors for our conceptualization of and argumentation about the physical, psychological and sociopolitical world that we experience; (b) the insight that linguistic meanings cannot be analyzed as isolated entities but only as parts of integration networks, which allow us to merge and superimpose conceptual domains and spaces so as to achieve ever more complex semantic constructions; (c) the insight that these constructions are not just ephemeral, but can become entrenched in the semantic systems of languages; and (d) an acknowledgement that such entrenched meaning complexes can be used as lexical and grammatical material for further innovative uses that lead to specific pragmatic effects and thus practical political effects as well. The notion of states or other political entities as containers, for instance, taps into a fundamental schema of bodily and psychological conceptualization - the Self as a bounded and self-contained entity - and thus relates to universal and, possibly, transhistorical structural principles of embodied thought, as highlighted by Conceptual Metaphor Theory and Embodiment Theory (Gibbs, 2005; Lakoff \& Johnson, 1999). However, in order to capture its actual communicative 
and cognitive effects, this notion needs to be studied in its varying discourse contexts. Several of the contributions to this volume show that the container metaphor with its inside-outside distinction has served not just to represent but indeed to redefine the relationships of individual nation states with the conglomerate entity of the European Union and its boundaries vis-à-vis other such conglomerate entities - for example, Eastern Europe, the Balkans and so on.

It is here that Critical Discourse Analysis (CDA) becomes methodologically essential for our studies, because it focuses on studying the linguistic manifestations of power relationships and social identity construction (Fairclough, 1995; Hodge \& Kress, 1993; Wodak \& Chilton, 2005; Wodak et al., 1999). Employing a mix of pragmatic, semantic, stylistic and sociolinguistic methods, CDA studies all levels of expressing and also managing sociopolitical perception and action in texts and their media environments. Language use is thus conceptualized not so much as a mere representation of a pre-existing 'objective' reality, but as a tool to influence and shape the social environment itself, including both individual and collective identities.

Grammatical and lexical choices are of key importance in CDA: deictic or indexical expressions, such as personal pronouns and adverbs, serve to establish the deictic center; that is, the specific position from which a piece of discourse is being created that helps addressees position themselves in relation to what is presented in a text (Chilton, 2004). With lexical choices, discourse producers define the border between 'us' and 'them'. Lexical choices happen to be among the most important elements of strategies of positive self-presentation and negative other-presentation (Van Dijk, 2006). Lexical choices are also crucial means in legitimization and delegitimatization strategies (Cap, 2008; Chilton, 2004). Of equal importance in discourse study are forms of implicit meanings in a text or utterance that are not overtly expressed, such as implications, presuppositions and allusions (Van Dijk, 2002). Discourse analysis concentrates on language means in creating discursive reality. However, this analysis is simultaneously a cognitive and social analysis that highlights the way we think about social reality and the social role of discourses.

The emphasis on lexical and grammatical choices and on the argumentative and discursive function of metaphors and other conceptual integration phenomena, such as metonymies and symbols, in identity construction has important consequences for the analyses in this book. Although the existence of relatively static, general and possibly universal conceptual integration networks is not denied, the main focus is on the variation, historicity and contested status of such concepts across regional, national and subnational boundaries. International political debates at times of momentous political upheaval, such as that experienced by the countries on Europe's eastern rim since the 1990s, exhibit a maximum. 
of discursive change and variation (and they demand a matching communicative flexibility from their participants). Hence, the respective national Self's national/international Others, for instance, is continuously being redefined and threatens to render older entrenched symbols, metaphors and associated commonplace assumptions obsolete. Such previous metaphors and symbols do not, however, disappear from political discourse altogether; rather, they remain as competitors to the dominant key concepts and arguments, ready to be recycled whenever the occasion demands. Therefore, none of the following analyses of identity debates claims to capture the concept/image/attitude of a nation or an intranational or international grouping in the sense of a fixed, static consensus, but only the heterogeneous ensemble of competing notions and visions. These contested concepts are not the outcomes of automatic, unconscious mappings, but rather the products of highly conscious and sophisticated rhetoric that combines linguistic, iconic and other media-specific communication techniques to achieve effects in specific target-audiences. Ideally, such effects should be also demonstrable by way of quantitative analyses (Buch \& Helfrich, this volume; Charteris-Black, 2004; Deignan, 2005; De Landtsheer, 2009; Musolff, 2004).

Although further work is needed in this field, the mainly qualitative studies presented here aim to provide a framework of leading perspectives for the formulation of testable hypotheses about changes in the relative weight of concepts and trends in discourses about Europe's eastern rim. These include the following research questions: How are European transitions presented nationally and cross-nationally? Does the metaphorical inventory change with the changing images of insideroutsider relationships? How are strategies of constructing identities and perceived cultural differences among the new EU member states related to each other? What happens to shared European metaphors in national discourses, and how are different discourse types (regional, national and supranational) interrelated? The focus is on strategies in conceiving national/cultural belonging and exclusion, perpetuating entrenched cultural images and contrasts, creating new images and reconstructing/ deconstructing value systems.

Some contributions to this book explore these issues by devoting particular attention to the countries of the former Yugoslavia and Turkey. Nation-building was a painful process throughout the 1990s, after Slovenia, Croatia, Macedonia and Bosnia-Herzegovina declared independence from Yugoslavia. Within a microcosm of ethnic and religious diversity, this sparked protracted warfare and ethric cleansing, which was halted only after international intervention in Bosnia in 1995, Kosovo in 1999 and Macedonia in 2001. Kosovo's declaration of independence in February 2008 was largely seen as the last step in the dissolution of the former Yugoslavia. Slovenia was the only former Yugoslav country 
to be included in the 2004 enlargement. Croatia's accession was blocked by former President Tuđman's autocratic leadership, Croatia's troublesome cooperation with the International Criminal Tribunal for the former Yugoslavia (ICTY) and continued human rights abuses against the country's Serbian minority. Since 2000 the situation has improved, and membership negotiations with the EU started in 2005. Macedonia gained candidate status in 2005, but no formal membership negotiations have commenced as yet. The same is true for Bosnia-Herzegovina, which signed a Stabilization and Association Agreement with the EU in June 2008. This can be seen as a first step toward accession. Serbian and Montenegrin accession are contested both within the two countries and within the EU, and will be preceded by lengthy negotiations (Cini, 2007, chapter 26; Smith, 2005).

These political developments are the context for most of the case histories in the second part of the volume. It continues the analysis of insiderness versus outsiderness, focusing on the neglected topic of southeast Europe as presented in public discourse both in the region and abroad. Because analytical treatment of discourse relating to southeast Europe is new, this section is given special prominence. Since the 1990s, the Balkan region has been the subject of extensive media coverage, with its concomitant images of regions, peoples, cultures and histories. For the most part, however, presentations have alternated between traditional stereotypes and simplified representations. Stereotypical images have been widely spread via the writings of diverse Balkan experts based on their experience as journalists, politicians or travelers, but even via scholarship dealing with this region (Fleming, 2000). This is observable in the titles of some books alone: for example, Der Balkan. Das Pulverfaß Europas (The Balkans: The Powder Keg of Europe; Herm, 1993), Pulverfass Balkan. Mythos oder Realität (The Balkan Powder Keg: Myth or Reality; Angelova \& Veichtlbauer, 2001) and Balkan Ghosts: A Journey Through History (Kaplan, 1993). Part of nonspecialist and scholarly writing has renewed old stereotypes, and part has tried to relativize these stereotypes. However, even these writers, in choosing eye-catching titles that suggest an image of the Balkans as a wild, unstable and dangerous place, contributed to spreading simplified images. Stereotypical images that emerged in foreign discourses helped formulate opinions among the general public, including policymakers. Controversy has surrounded not only foreign portrayals of southeast Europe, but also the region's own self-definitions. Simplified images of nations and their culture have been borrowed in domestic discourses and partly internalized. During and after the wars in the Balkans, self-definition underwent various phases and transformations. Following violent upheavals, it was constructed anew or reconstructed once again. Today, identities in southeast Europe alternate between externally ascribed and self-declared characterizations. 
On the one hand, all southeast European countries have made claims of European centrality and primacy in various discourses (e.g. 'Serbia in the very heart of Europe', 'Croatia in the heart of Europe'; Ježić, 1996); on the other hand, they have partly internalized images imposed from outside. Bakić-Hayden and Hayden (1992: 3) argue that Orientalist rhetoric (i.e. terms with negative connotations employed in describing the Balkans and frequently used by outsiders) is 'often used even by those who are disparaged by them'. Trying to depart from the images that could call into question their 'Europeanness', southeast Europeans have tried to identify and characterize the Other among their neighbors. They have frequently used the same rhetorical strategies in creating stereotypes as some foreign discourses - characterized as discriminatory - have done. Fleming (2000) points toward the liminality of the Balkans, and how its location between multiple domains may have been a reason for its past ambivalent discursive descriptions. The author recognizes a need for extensive analyses to explain the complex relation of self-perceptions and the ways this region has been conceptualized from outside (Fleming, 2000: 1232). Several contributions in this book are a step in this direction.

The text material examined in the second part of the volume derives from various media text corpora, from within and outside of the region, that thematize the varying concepts of the Balkans and southeast Europe. Comparing the view of South Slavic countries from within and without, this section seeks to outline the recent dominant models of perception, reception and representation of the Self and the Other. An important identity concept here is contained in the term Balkan, which has played a central role in foreign media portrayals of the region and in the region's own self-definition (Bakić-Hayden, 1995; Bakić-Hayden \& Hayden, 1992; Brown \& Theodossopoulos, 2004; Jansen, 2002; Lindstrom, 2003; Lindstrom \& Razsa, 2004; Šarić; Vezovnik, this volume; Todorova, 1997). In connection with the thesis of two Europes, coined by the Croatian writer Miroslav Krleža, whose seminal work is discussed in Hudabiunigg (this volume), the concept of the Balkans offers a boundary and consolidation of identity (Krleža, 1989, 1990; Škvorc, 2001). The metaphors and cultural constructs that create a dichotomy between 'Europe' and the Balkans raise the following questions: What does this dichotomy mean in different media contexts? What is the significance of the metaphorical borders between 'Europe' and the Balkans (e.g. an intended dividing line between East and West)? What other metaphorical concepts are placed in opposition to the Balkans? The discourse examined is thematically related to the events that have been important for the political development of the Balkans (e.g. debates surrounding EU expansion, Slovenia's holding the EU presidency in 2008 and the independence of Kosovo and Montenegro).

The contributions in the first and second parts shed light on the models of formulating images of the Self and the Other in the selected corpora, 
as well as the transformations that have been influenced by political and social processes. The individual chapters are mostly oriented toward the analysis of media texts, which are interpreted as expressions of current political debates and indicators of social and cultural changes. Media discourse is not only about texts: It also comprises pictorial representations, such as headlines and photographs, that interact with text and context features. Several chapters link the discourse-analytical approach to social science findings on public opinion and sociocultural stereotypes, as well as to changes in popular interpretations of national and regional histories. The selected texts are the result of interactions between political and cultural agents at a particular point in time. The main focus of these analyses is the implications and effects of rhetorical strategies used in their respective contexts: What can one learn from their use about the intended readers/listeners, and about the entire society in which they are created and received? Can these conceptual and rhetorical strategies serve as a means of manipulating opinions? In which sense can they be said to be effective or ineffective? Can they promote peace, conflict, hatred and tolerance?

Stefan Manz investigates the immediate effect of Poland's EU accession on German-Polish relations. By analyzing a set of cross-national debates and friction points, he demonstrates that accession did not necessarily improve bilateral relations. Instead, the new closeness reinforced negative perceptions and long-held mutual suspicions. The two case studies discussed in detail are the discourse surrounding postwar expellees from former German territories and the question of the EU voting structure. Both discourses show that bilateral relations are increasingly negotiated at the EU level.

Steffen Buch and Uta Helfrich concentrate on three newspapers (Le Figaro, Le Monde and Libération) to highlight metaphorical strategies employed by the French press to prepare the public for accession. France and, to a certain extent, Germany are constructed as legitimate, dominant and high-status EU-group members by being identified as LEADERS and MOTORS. Hierarchies are also conveyed through the SCHOOL and FAMILY concepts, which assess the ability of newcomers to integrate and assume their ostensibly rightful place within the EU framework.

Similar conceptualizations can be detected in the Lithuanian and German discourses, as Sandra Petraškaite-Pabst shows in her comparative analysis. Through metaphors such as LOCOMOTIVE, ENGINE and ADVOCATE, Germany is seen to assume a leading role in the enlargement process, whereas the scHool concept is also widely used within Lithuanian discourse in order to convey that the country has to catch up after 50 years of Soviet rule. A different set of culture-specific metaphors referring to Lithuanian fairy tales, customs and history is employed to increase the 
emotional identification of the Lithuanian public with distant, eurocratic Brussels.

Most of the chapters in the second part of the book focus on the former Yugoslav countries. Up to 1991, various South Slavic and other nations lived in a common state, Yugoslavia. In the official ideological framework and rhetoric, they were considered 'brothers' and 'fraternal nations'. Still, times have greatly changed since Yugoslavia's violent demise in the early 1990s: Slovenia joined the EU in 2004, thus institutionally acquiring a markedly different position than the other countries. Slovenia's EU accession and its holding the EU presidency in 2008 initiated lively discussions in public discourse outside Slovenia, in which Slovenia's identity has been redefined and its image presented to the rest of Europe (see Šarić; Vezovnik, this volume). Hyder Patterson (2003) examines Slovenian discourses in the late 1980s and early 1990s aimed at reestablishing Slovenian identity links to Central Europe and differentiating it from the Balkans. Mihelj et al. (2009) analyze Slovenian news programs from the late 1980s and the early 1990s and demonstrate how the semantic scope of deictic expressions shifted, and the role that shift played in dissociating the Slovenians from their Yugoslav 'brothers'. Redefinitions of cultural identity have also taken place in other former Yugoslav countries since the 1990s. Two important social events have given these discussions a decisive impulse: violent conflicts in the 1990s in which ethnic groups belonging to warring sides (Croats vs. Serbs and Bosniaks, Serbs vs. Bosniaks and Croats in armed conflicts in Croatia and Bosnia, Serbs. vs. Albanians in Kosovo, Albanians vs. Macedonians in Macedonia, etc.) tried to legitimize their own actions and delegitimize actions of the Other (see Kolstø, 2009, for a study of identity formation and media discourse during the Yugoslav conflicts). The second event in the postconflict period is public discussions related to the EU accession prospects of the former Yugoslav countries, in which various ethnic and political groups have been seeking to reestablish their Europeanness, which has been seen as strongly questioned or denied in some foreign discourses during and immediately after the wars of Yugoslav secession. In recent years, all of the former Yugoslav countries have been seeking to define and redefine themselves in relation to their immediate neighbors, and to the EU.

Most chapters in the second part of this book follow the discursive identity formulation practices of the former Yugoslav countries in their own and foreign public spaces. Ljiljana Šarić examines how identity patterns ascribed to post-Yugoslav societies from outside and inside relate to metaphorical geography and the term the Balkans. In a corpus of Germanlanguage, Croatian and Serbian media texts from 2008, various attitudes to metaphorical geography are identified. Whereas in the German-language media contexts the Balkans is mostly a neutral geographical label, a dual tendency can be traced in the Croatian media: A critique of the usage of 
the Balkans as a negative identity label is frequently accompanied by discursive practices in which unwanted societal phenomena are labeled as Balkan. In Serbian media, Balkan-related terms are much less contested, and more frequently used in instant self-identifications.

Dubravka Kuna and Branko Kuna focus on how Croats see their neighbors: Bosniaks, Serbs, Slovenians and Montenegrins. In a corpus of Croatian media texts from 2007, they follow various naming strategies for the neighboring South Slavic nations (specifically, conscious and deliberate name conversions), and examine the linguistic structure of name modifications. Unofficial names such as discriminatory expressions from populist discourse are contextually determined and linked to social circumstances. In naming the Other, not only an interplay of prejudices and stereotypes about both the Self and the Other plays a role, but also text genres, personal convictions and political standpoints. This analysis shows that the wars of Yugoslav secession, and other past and present conflicts, are still present in media discourse.

Daphne Winland's chapter follows political rhetoric in contemporary Bosnia and the continual contesting of the grounds of identity evidenced in the clash of competing narratives in the service of political aims. Departing from the thesis that inflammatory rhetoric about Islam serves to promote local, regional or national interests, she examines how discourses that have emerged with the 'War on Terror' affect local populations in Bosnia. The chapter's focus is on Bosnian Croats in particular and how they see their future as a constituent nation in Bosnia. It investigates how anti-Muslim sentiments are strategically deployed by elites in the service of different ambitions and interests, and how they are framed ideologically, culturally and historically to suit local contexts. The analysis calls attention to the need to consider factors generated in localized contexts.

Tatjana Radanović Felberg's chapter presents an example of identity negotiations between the Serbian and Montenegrin governments during the NATO bombing of the Federal Republic of Yugoslavia in 1999. Focusing her analysis on the front pages of two newspapers (Serbian Politika and Montenegrin Pobjeda) that supported the respective national governments and presidents, she considers a range of semiotic features, and a variety of their functions in building political identities. It is observed that the visual dimension of front pages relates to the different ideological positions. Politika supported Milošević's government, seeking to construct Milošević's identity as a strong leader and defender of the nation vis-à-vis world powers such as the United States and NATO, whereas Pobjeda tried to maintain an image of Đukanović as a pro-Western leader in which Montenegro was aligned with Europe.

Andreja Vezovnik's contribution to this book concentrates on the period from January 2001 to December 2003 in Slovenia, the time of the most intense public discussions on joining the European Union. She 
analyzes the historical and intertextual links between Slovenian national identity (re-)construction as a 'European' country after the break-up of the former Yugoslavia and the nineteenth century of 'Krekism', which formulated a Slovenian identity within the context of the Austro-Hungarian Empire. Whereas some metaphors and symbols of Krekist discourse (the nation as mother, and the ideal of the diligent, hard-working and God-fearing farmer) have been resurrected, other aspects of traditional Slovenian selfperception have become problematic in the process of joining the EU; for example, fears of being overpowered by foreign influence and being relegated to second-rank or even 'servant' status of a supranational authority.

Pawel Bak looks at metaphors in the Polish press that comment on the $\mathrm{EU}$ accession of various 'Balkan' countries, ranging from Bulgaria and Romania to Croatia, Serbia and Montenegro. In comparison with Western (mainly German) conceptualizations of these countries, his corpus data show, on the one hand, a roughly similar array of metaphors, including CONTAINER, ROAD-MOVEMENT, HOME and FAMILY. On the other hand, however, the emphasis in publications is focused on integration models, which allow for an active role of the new accession countries (rather than making them the objects of EU expansion).

The final chapter in this part focuses on a country outside the former Yugoslav scope: Turkey. Turkey started EU entry talks in 2005 along with Croatia, and its EU prospects have frequently been discussed in the same context with the prospects of the former Yugoslav countries. Andreas Musolff studies the conceptualization of the potential accession state of Turkey in the German press. He distinguishes three metaphorical models or scenarios that are used to portray Turkey's current relationship to Europe: (1) Turkey as an outsider with little chance of ever getting access into the EU house/family/club, (2) that of Turkey's progress toward and future inclusion in the EU and (3) a collision/conflict scenario. In terms of the quantitative distribution in the German press corpus, the pessimistic scenarios (1) and (2) outweigh the optimistic scenario (3) - a finding that ties in with social science research on public attitudes toward Turkey and to Turkish migrants in Germany.

To complement the analyses of political and media discourse in the preceding parts, the contributions in the third part concentrate on literary texts that thematize contested national and cultural identities. This part uses literary hermeneutics to investigate literature as a point of intersection for various strands of historical and current discourses that underlie and inform the changing images of Europe in political and media discussions. The case studies reveal the emergence of a multiplicity of perspectives on national identities as self/other or as insider/outsider because literature shows a special interest in reconstructing and reexamining 'otherness' (Hammond, 2004; Longinović, 1995; Škvorc, 2001). The 
respective analyses focus on new ways of understanding national and ethnic identities in contemporary Polish literature, traditionalism versus modernism in the construction of a new identity in Montenegrin society and contesting the border between East and West in the work of one of the most significant Croatian authors of the twentieth century.

Ingrid Hudabiunigg's chapter focuses on the notion of two Europes, which Croatian writer Miroslav Krleža established in essays and political speeches. In these, the author challenges the widespread opinion by Western media that the center has always been located in the west of the continent, whereas East-Central Europe, and especially the Balkans, are at the uncivilized periphery. Krleža claims that presenting Europe with only one center goes hand in hand with the political and economic domination and exploitation of Western powers over the countries of the East. With this form of deconstruction, Krleža can be seen as a forerunner to Pierre Bourdieu and his theory of the 'linguistic market', linking political dimensions of conflicts to particular world visions in a dialectic relationship. The author argues instead for a common Europe with two poles, by which the achievements of great philosophers, writers and artists in East-Central Europe would be justifiably appreciated.

A picture of cultural change in post-Yugoslavia is drawn by Biljana Jovanović Lauvstad in her review of Balša Brković's best-seller Privatna Galerija (Private Gallery). In contrast to the predominant heroic literature (epika) of Montenegro depicting the bravery and patriotism of male heroes, Privatna Galerija is written in the first-person singular from the perspective of a young man rebelling against the patriarchal-heroic codex of masculinity. The protagonist's private life and his intimate relationships with several women are extensively focused on. Lauvstad looks at the self-presentation of the main character and the articulation of 'the new sensibility' in postmodern gender relations applying critical feminist reading.

Knut Andreas Grimstad's chapter gives a survey of Polish public discourse (novels, stories, essays and TV productions) on Jews after the fall of communism. He analyses several distinct rhetorical-discursive devices for the Polish-Jewish cultural legacy, including images of a multicultural past in Polish-Jewish small-town communities, the Holocaust and the mass expulsions of 'Zionists' in 1968 and a critique of xenophobic and nationalist tendencies in post-communist Poland. As a literary response to the antidemocratic trends in post-totalitarian Poland, writers such as Szewc, Rymkiewicz, Lubkiewicz-Urbanonowicz and Krall, according to Grimstad, contribute to a deconstruction of Jewish as well as other minority-related enemy images and may be understood as the very basis for a literary project of modernization.

What emerges from the analysis of various discourses considered in this book is not a static or homogeneous picture of the 'family of 
European nations' but rather a dynamic and open-ended continuum of discourses that seek to redefine and reassess the 'family resemblances' among its different members (and groups of members), including the hitherto ostracized eastern 'branch of the family'.

\section{Note}

1. See Dobrodošli u Srbiju 'Welcome to Serbia', at: http://www.serbiatourist guide.com/live/?languageld=4. Accessed 15 August 2009.

\section{References}

Angelova, P. and Veichtlbauer, J. (2001) Pulverfaß Balkan. Mythos oder Realität. St Ingbert: Rörig Universitätsverlag.

Bakić-Hayden, M. (1995) Nesting orientalism: The case of former Yugoslavia. Slavic Review 54 (4), 917-931.

Bakić-Hayden, M. and Hayden, R.M. (1992) Orientalist variations on the theme "Balkans:" Symbolic geography in recent Yugoslav cultural politics. Slavic Review 51 (1), 1-15.

Brown, K. and Theodossopoulos, D. (2004) Other's others: Talking about stereotypes and constructions of otherness in Southeast Europe. History and Anthropology $15(1), 3-14$.

Cap, P. (2008) Towards the proximization model of the analysis of legitimization in political discourse. Journal of Pragmatics 40 (1), 17-41.

Charteris-Black, J. (2004) Corpus Approaches to Critical Metaphor Analysis. Basingstoke: Palgrave-Macmillan.

Chilton, P. (2004) Analysing Political Discourse. Theory and Practice. London: Routledge.

Cini, M. (2007) European Union Politics. Oxford: Oxford University Press.

De Landtsheer, C. (2009) Collecting political meaning from the count of metaphor. In A. Musolff and J. Zinken (eds) Metaphor and Discourse (pp. 59-78). Basingstoke: Palgrave-Macmillan.

Deignan, A. (2005) Metaphor and Corpus Linguistics. Amsterdam/Philadelphia: Benjamins.

Fairclough, N. (1995) Critical Discourse Analysis. The Critical Study of Language. London: Longman.

Fauconnier, G. and Turner, M. (2002) The Way We Think: Conceptual Blending and the Mind's Hidden Complexities. New York: Basic Books.

Fleming, K.E. (2000) Orientalism, the Balkans, and Balkan historiography. The American Historical Review 105 (4), 1218-1233.

Gibbs, R.W. Jr. (2005) Embodiment and Cognitive Science. Cambridge: Cambridge University Press.

Grady, J., Oakley T. and Coulson, S. (1999) Blending and metaphor. In R.W. Gibbs and G. Steen (eds) Metaphor in Cognitive Linguistics (pp. 101-124). Amsterdam: Benjamins.

Hammond, A. (ed.) (2004) The Balkans and the West: Constructing the European Other, 1945-2003. Aldershot: Ashgate.

Herm, G. (1993) Der Balkan. Das Pulverfaß Europas. Düsseldorf: Econ.

Hodge, R. and Kress, G. (1993) Language as Ideology. London: Routledge. 
Hyder Patterson, P. (2003) On the edge of reason: The boundaries of Balkanism in Slovenian, Austrian, and Italian discourse. Slavic Review 62 (1), 110-141.

Jansen, S. (2002) Svakodnevni orijentalizam: doživljaj "Balkana" "Evrope" u Beogradu i Zagrebu. Filozofija i društoo: Journal of the Belgrade Institute for Social Research and Philosophy 18, 33-72.

Ježić, M. (ed.) (1996) Hrvatska u srcu Europe: sredozemni i srednjoeuropski kulturni krajolici Hrvatske. Zagreb: Hrvatska paneuropska unija.

Kaplan, R.D. (1993) Balkan Ghosts: A Journey through History. New York: St. Martin's Press.

Kolstø, P. (2009) Media Discourse and the Yugoslav Conflicts. Representations of Self and Other. Aldershot: Ashgate.

Kövecses, Z. (2005) Metaphor in Culture: Universality and Variation. Cambridge/New York: Cambridge University Press.

Krleža, M. (1989) Krokodilina ili razgovor o istini. Sarajevo: NIŠRO Oslobođenje.

Krleža, M. (1990) Deset krvavih godina. Sarajevo: Veselin Masleša.

Lakoff, G. and Johnson, M. (1980) Metaphors We Live By. Chicago: University of Chicago Press.

Lakoff, G. and Johnson, M. (1999) Philosophy in the Flesh. The Embodied Mind and Its Challenge to Western Thought. New York: Basic Books.

Lindstrom, N. (2003) Between Europe and the Balkans: Mapping Slovenia and Croatia's "return to Europe" in the 1990s. Dialectical Anthropology 27 (3-4), 313-329.

Lindstrom, N. and Razsa, M. (2004) Balkan is beautiful: Balkanism in the political discourse of Tuđman's Croatia. East European Politics and Societies 18 (4), 628-650.

Longinović, T.Z. (1995) East within the west: Bosnian cultural identity in the works of Ivo Andrić. In W.S. Vucinich (ed.) Ivo Andrić Revisited: The Bridge Still Stands (pp. 123-138). Berkeley: University of California International and Area Studies Digital Collection 92.

Manz, S., Musolff, A., Long, J. and Sarić, Lj. (eds) (2004) Discourses of Intercultural Identity in Britain, Germany and Eastern Europe. Special Issue: Joumal of Multilingual and Multicultural Development 25 (5 \& 6), 437-452.

Mihelj, S., Bajt, V. and Pankov, M. (2009) Reorganizing the identification matrix: Televisual construction of collective identities in the early phase of Yugoslav disintegration. In P. Kolsto (ed.) Media Discourse and the Yugoslav Conflicts. Representations of Self and Other (pp. 39-59). Aldershot: Ashgate.

Musolff, A. (2004) Metaphor and Political Discourse. Analogical Reasoning in Debates about Europe. Basingstoke: Palgrave-Macmillan.

Semino, E. (2008) Metaphor in Discourse. Cambridge: Cambridge University Press.

Skvorc, B. (2001) Srednja Europa i Balkan u Krležinim romanima: Problematika tekstualnih i izvantekstualnih književnih interakcija. Republika 57 (7-8), 56-77.

Smith, K.E. (2005) Enlargement and European order. In C. Hill and M. Smith (eds) International Relations and the European Union (pp. 270-291). Oxford: Oxford University Press.

Todorova, M. (1997) Imagining the Balkans. Oxford: Oxford University Press.

Van Dijk, T. (2002) Critical discourse studies: A sociocognitive approach. In R. Wodak and M. Meyer (eds) Methods of Critical Discourse Analysis (pp. 95-120). London: Sage.

Van Dijk, T. (2006) Discourse and manipulation. Discourse \& Society 17 (2), 359-383. 
Wodak, R., de Cillia, R., Reisigl, M. and Liebhart, K. (eds) (1999) The Discursive Construction of National Identity. Edinburgh: Edinburgh University Press.

Wodak, R. and Chilton, P. (eds) (2005) A New Agenda in (Critical) Discourse Analysis. Theory, Methodology and Interdisciplinarity. Amsterdam/Philadelphia: Benjamins.

Zinken, J. (2007) Discourse metaphors: The link between figurative language and habitual analogies. Cognitive Linguistics 18 (3): 445-466.

Zinken, J. and Musolff, A. (2009) A discourse-centred perspective on metaphorical meaning and understanding. In A Musolff and J. Zinken (eds) Metaphor and Discourse (pp. 1-10). Basingstoke: Palgrave-Macmillan. 